Research Paper

\title{
Cyclin-Dependent Kinases 4/6 Inhibitors in Breast Cancer: Current Status, Resistance, and Combination Strategies
}

\author{
Ying $\mathrm{Niu}^{1}$, Junnan $\mathrm{Xu}^{1,2}$ and Tao Sun ${ }^{1,}$ \\ 1. Department of Medical Oncology, Cancer Hospital of China Medical University, Liaoning Cancer Hospital and Institute, No. 44 Xiaoheyan Road, Dadong, \\ Shenyang, Liaoning 110042, P.R. China \\ 2. Key Laboratory of Liaoning Breast Cancer Research, Shenyang, Liaoning 110042, P.R. China
}

$\square$ Corresponding author: Dr Tao Sun, Department of Medical Oncology, Cancer Hospital of China Medical University, Liaoning Cancer Hospital and Institute, No. 44 Xiaoheyan Road, Dadong, Shenyang, Liaoning 110042, P.R. China. Tel: +86 02431916341; Fax: +86 02431916341; E-mail: suntao@cancerhosp-ln-cmu.com

(c) The author(s). This is an open access article distributed under the terms of the Creative Commons Attribution License (https://creativecommons.org/licenses/by/4.0/). See http:/ /ivyspring.com/terms for full terms and conditions.

Received: 2018.12.28; Accepted: 2019.08.06; Published: 2019.08.29

\begin{abstract}
Dysregulated activation of the cyclin-dependent kinases (CDKs) 4/6, leading to uncontrolled cell division, is hallmark of cancers. Further study of the cell cycle will advance the cancer treatment. As powerful and effective drugs, inhibitors of CDK $4 / 6$ have been widely used in clinical practice for several malignancies, particularly against breast cancers driven by the estrogen receptor (ER). Three CDK4/6 inhibitors, including palbociclib (PD0332991), ribociclib (LEE011) and abemaciclib (LY2835219), have been approved by the US Food and Drug Administration (FDA) for the treatment of hormone receptor-positive, human epidermal growth factor receptor 2-negative advanced or metastatic breast cancer. However, CDK4/6 inhibitors act downstream of many mitogenic signaling pathways, and this has implications for resistance. It is worth to note that the mechanisms of resistance are not very clear. Up to now, a small number of preclinical and clinical studies have explored potential mechanisms of CDK4/6 inhibitors resistance in breast cancer. On this basis, rational and effective combination therapy is under development. Here we review the current knowledge about the mechanisms and efficacy of CDK4/6 inhibitors, and summarize data on resistance mechanisms to make future combination therapies more accurate and reasonable.
\end{abstract}

Key words: CDK 4/6 inhibitors, breast cancer, clinical trials, drug resistance, combination treatment

\section{Introduction}

The cell cycle is a critical regulator of cell proliferation, growth and division after DNA damage. It controls the transition from the quiescent state (G0 phase) to cell proliferation and passes through checkpoints [1]. To enter DNA synthesis (S phase), all cells must activate cyclin-dependent kinases (CDKs), which require binding to a cyclin subunit to become catalytic active. The D-type cyclins and their partner kinases, $\mathrm{CDK} 4$ and 6, play important role in cell cycle (Figure 1) [2,3]. Activation of upstream mitogenic pathways, including PI3K-AKT-mTOR, RAS-RAF-MEK-ERK and estradiol can enhance cyclin D-dependent CDK4/6 activity
(Figure 2) [4]. In breast cancer, cyclin D1 amplification and CDK4 copy gain are common in luminal and HER2-enriched subtypes but are rare in basal-like tumors with $R b$ loss or mutation and cyclin E1 amplification [5]. Numerous preclinical studies have shown that cyclin D1-CDK4/ 6 is a necessary factor in sustaining the tumorigenic potential of breast cancer cells [6-8].

Given the critical role of CDKs in the cell cycle, it is not surprising that work has been done on developing selective CDKs inhibitors. Pan-CDK inhibitors were the first generation of this class of drugs and were quickly abandoned due to their 
toxicity profile for normal cells, which led to severe side effects and difficulties to determine an effective dose [9-11]. These issues have been overcome by more selective targeting of CDK 4 and 6, which mediate transition from G0/G1 phase to $S$ phase of the cell cycle [12]. Selective CDK4/6 inhibitors have been developed and have altered the systemic treatment pattern in breast cancer patients. Preclinically, cell lines that represented luminal estrogen receptor positive (ER-positive) subtype, including those that were human epidermal growth factor receptor 2 (HER2) amplified, were the most sensitive to growth inhibition by palbociclib. Furthermore, strong synergistic effects have been observed when CDK4/6 inhibitors were added to standard anti-estrogen therapies [13]. Several randomized clinical trials have shown the application of CDK4/6 inhibitors as a valuable clinical approach (Table 1 ). As a result, three CDK4/6 inhibitors, including palbociclib (Ibrance), ribociclib (Kisqali) and abemaciclib (Verzenio), have been approved by the US Food and Drug Administration (FDA) for treatment of hormone receptor (HR)-positive/human epidermal growth factor receptor-2 (HER2)-negative advanced or metastatic breast cancer. There is no approval for HER2-positive disease yet [14].

Notably, despite the clinical benefits of CDK4/ 6 inhibitors, tumor resistance is developing in the metastatic patients and the mechanisms for this resistance are not clear. Preclinical studies are exploring mechanisms of resistance and few clinical studies have reported resistance mechanisms in breast cancer patients. Moreover, studies are currently ongoing aimed to identify combined treatments that might prevent early adaptation of breast cancer cells to the antitumoral effects of CDK4/ 6 inhibitors. In this review, we focus on the mechanisms of action and efficacy of CDK $4 / 6$ inhibitors and discuss therapeutic approaches to overcome drug resistance.

\section{The role of CDK4/6 inhibitors in breast cancer}

In most adult tissues, differentiated cells are almost always maintained in a G0 phase, these cells are thought to be dormant and wait to enter the cell cycle [4, 15]. Appropriate mitogenic stimuli, such as growth factors and hormones, can trigger the cell cycle and induce the progression from G0/G1 phases to $S$ phase [15].

Cell cycle transitions are governed by CDKs' activity [16]. In metazoans, the majority of cell cycle entry is controlled by CDK $4 / 6$ proteins, which respond to numerous growth regulatory signals [17]. CDK4 and CDK6 are serine/threonine kinases that contain a 300-aminoacid catalytic domain usually inactive. When the cells are ready to initiate DNA synthesis in mammalian cells, CDK4/ 6 complex binds to D-type cyclins (cyclin D1, cyclin D2 and cyclin D3) and mediates progression through the G1 phase (Figure 1) [18]. The kinase activity of CDK4/6 is strictly regulated by a plethora of CDK inhibitors (CDKi), which acts to inhibit cell cycle progression under adverse conditions. CKIs are subdivided into two categories, according to its structure and CDK specificity. Members of the INK4 family [p16INK4a (Cdkn2a), p15INK4b (Cdkn2b), p18INK4c (Cdkn2c) and p19INK4d $(C d k n 2 d)]$ primarily target CDK4 and

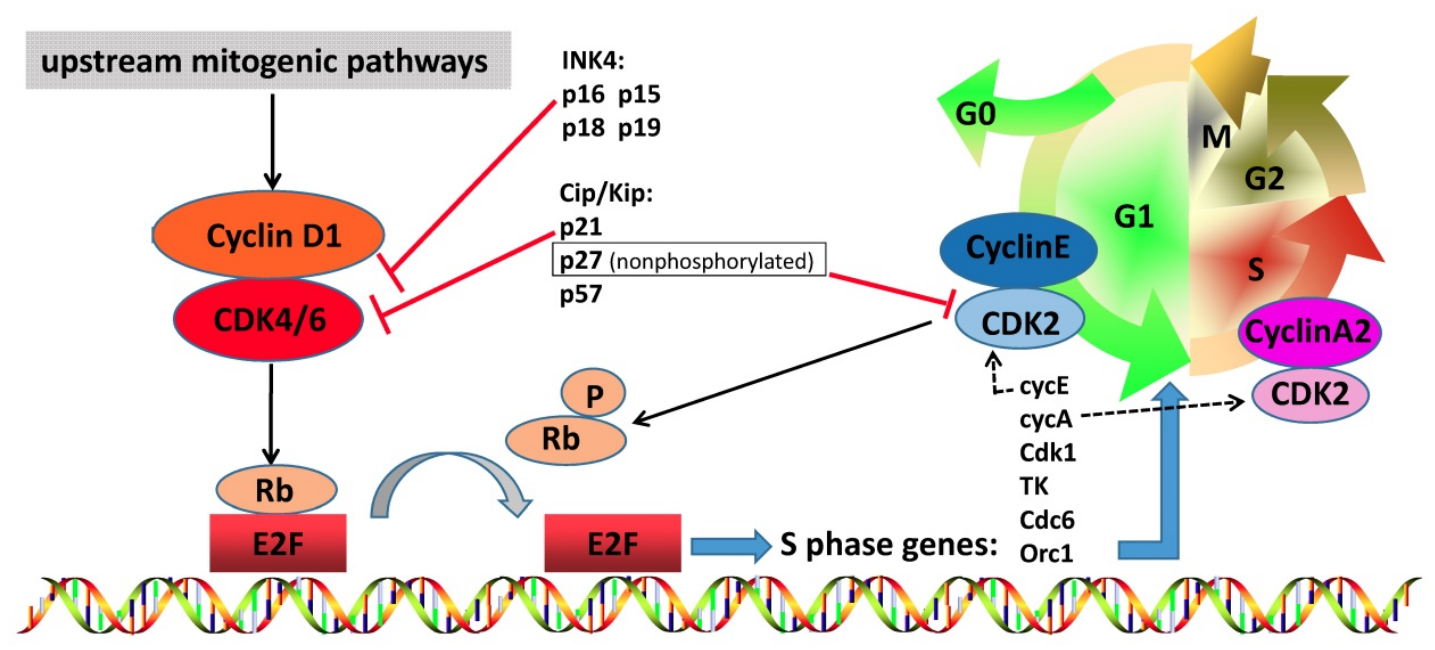

Figure 1. The role of cyclin D-CDK4/6-INK4-Rb pathway in breast cancer. CDK4 and CDK6 play a very important role in cell cycle entry, including cross talk with other oncogenic signal pathways. When the cell prepares to initiate DNA synthesis, upstream mitogenic pathways increase cyclin DI levels, which may activate CDK4/6. Active complex of CDK4/6 and cyclin D1 phosphorylates and inactivates RB protein, which is then phosphorylated by other complexes such as cyclin E-CDK2 in the late G1 phase. Phosphorylated RB releases transcription factor E2F, permitting the up-regulation of E2F activation and transcription of client genes required for cell cycle G1/S transition. Cyclin A2-CDK2 complex increases and phosphorylates proteins involved in DNA synthesis, thereby driving $S$ phase progression. The kinase activity of CDK4/6 is tightly suppressed by endogenous inhibitors, such as Cip/Kip family members (p21 Cip1, nonphosphorylated p27Kip1 and p57Kip2) and INK4 family proteins (p16INK4a, p15INK4b, p18INK4c and p19INK4d), and pharmacologic CDK4/6 inhibitors. And nonphosphorylated p27 suppress the CDK2 and has an oncogenic function to maintain cyclin D-CDK4 activity. 


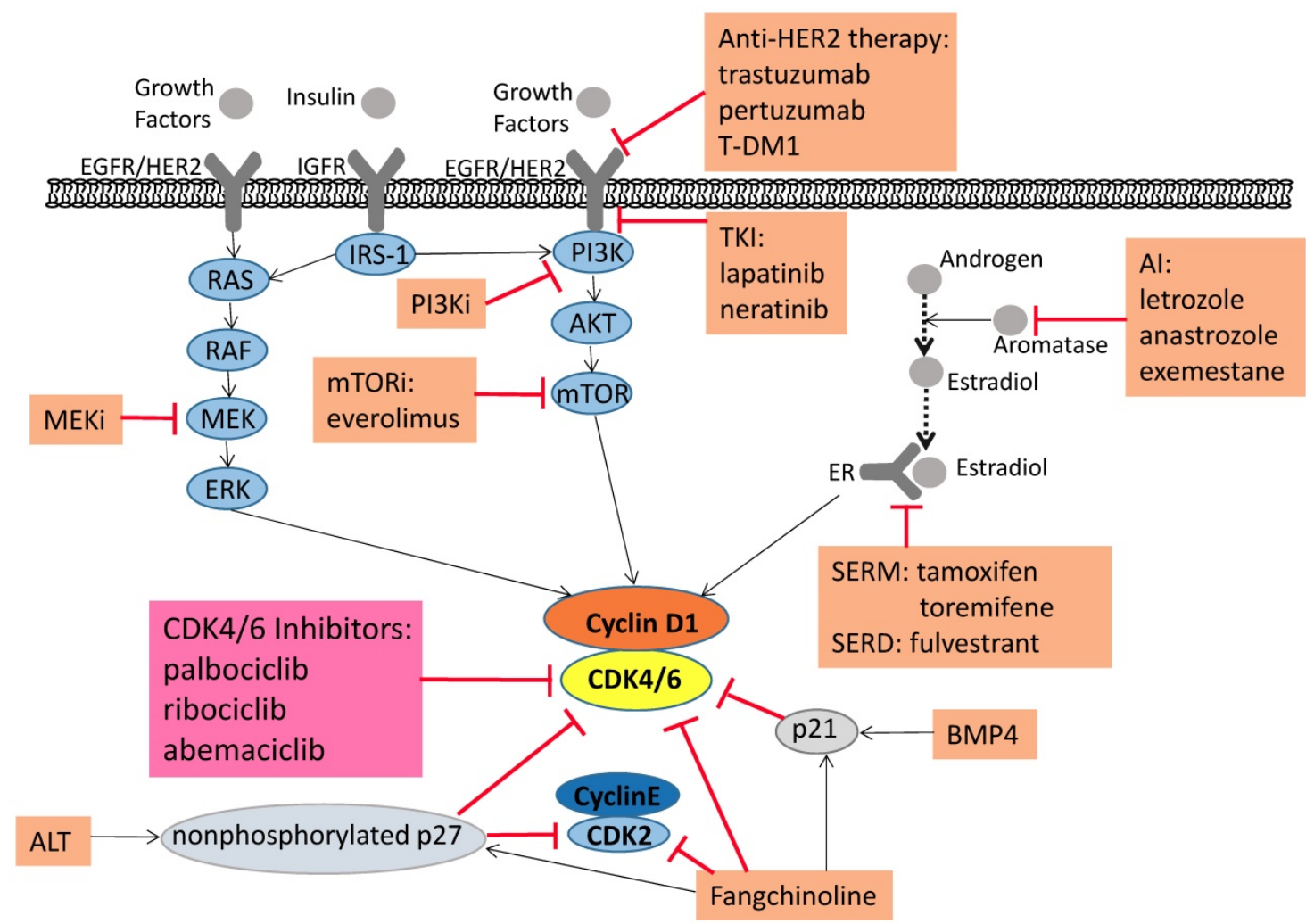

Figure 2. Signaling pathways associated with tumorigenesis and combined treatments that alleviate drug resistance. Pharmaceutical CDK4/6 inhibitors palbociclib, ribociclib, and abemaciclib directly inhibit CDK4/6 activity. Moreover, the upstream mitogenic forces, including the canonical RAS-RAF-MEK-ERK pathway, heightened activity of the HER2-PI3K-AKT-mTOR axis, increase the cyclin D1 levels, activating CDK4/6 and promoting cellular progression to the $S$ phase. Because of this foundation, PI3K, mTOR and MEK inhibitors induce synergistic anti-proliferative and pro-apoptotic effects, which lead to more durable cell cycle arrest and a delay to the onset of resistance. The Aromatase Inhibitors (Al), which inhibit the transformation of androgen into estradiol, thereby suppress breast cancer cell growth. Selective estrogen receptor modulator (SERM) and selective estrogen receptor downregulator (SERD) can affect estrogen receptors to produce the same inhibitory effect on tumor cells. ALT can keep p27 in a non-phosphorylated state, which is a stable form, and reduce both CDK2 and CDK4 activity. BMP4 and Fangchinoline can upregulate p21. Fangchinoline not only increases the level of CKIs (p21 and p27), but also inhibits cyclin D1/D3/E and CDK2/4/6. The ALT, BMP4 and Fangchinoline are still under preclinical study. In addition, clinical studies on the combination of CDK4/6 inhibitors with anti-HER2 therapy and immunotherapy are under way.

CDK6 [19]. The INK4 proteins weaken the binding of D-type cyclins to CDK4/6 and interact with the catalytic domains of CDK4/6 to potently suppress kinase activity [17]. In contrast, the Cip/Kip family members [p21Cip1 (Cdkn1a), p27Kip1 (Cdkn1b) and p57Kip2 (Cdkn1c)] more extensively interfere with the activities of cyclin D-, E-, A- and B-dependent kinase complexes [19].

When cells pass G1 phase, cyclin D-CDK4/6 is the first complex to become active in G1, which results in the phosphorylation of their downstream target, the Retinoblastoma-associated protein $(\mathrm{pRb})$ (Figure 1) [20]. $R b$ is a tumor suppressor that regulates multiple critical cellular activities, including late G1 restriction point, DNA damage response checkpoints, cell cycle exit and differentiation [21]. The retinoblastoma family includes three members, $\mathrm{Rb} / \mathrm{p} 105, \mathrm{p} 107$ and $\mathrm{Rb} 2 / \mathrm{p} 130$, collectively referred to as "pocket proteins" [22]. Rb inhibits the expression of many genes normally activated by the E2F transcription factor, a family of protein that regulates genes involved in cell cycle control, mitotic progression and dNTP biosynthesis [20, 22, 23]. The hyperphosphorylation of $\mathrm{Rb}$ reduces the affinity for E2F, thereby making it possible to activate and transcribe the E2F-target genes required for cell division. Moreover, $\mathrm{Rb}$ is also phosphorylated by cyclin E-CDK2 in the late G1 phase [24]. Cyclin A2-CDK2 complex phosphorylates proteins such as pocket proteins ( $\mathrm{Rb}, \mathrm{p} 107, \mathrm{p} 130)$ and proteins involved in DNA synthesis, thus promoting the $S$ phase process [25]. Cyclin D-CDK4/6 complex also phosphorylates the transcription factor FOXM1 (Forkhead Box M1), which leads to FOXM1-dependent expression of genes that support cellular proliferation and suppress senescence induction [26].

The cyclin D-CDK4/6-INK4-Rb pathway is commonly dysregulated in a wide variety of human cancers, such as sarcoma, glioma, breast tumors, lymphoma, leukaemias and melanoma [27, 28]. Many studies have indicated that this pathway plays a vital role in the occurrence, development, precision medicine and prognosis of breast cancer [26, 29]. Defects in the principal late-G1 cell-cycle checkpoint regulated by $\mathrm{pRb}$, which may be universal in human 
cancers, include loss of RB1 protein and deregulation of the CDKs, also through direct over-activation of CDKs or genetic deletion of their inhibitors [30]. Cyclin D1 is overexpressed in over $50 \%$ of breast cancers [31]. Amplification and overexpression of cyclin D1 may contribute to its oncogenicity, and the oncogenic predisposition occurs within luminal tumors, more specifically within Luminal B breast cancers [32-34]. Cyclin D1 is a product of the CCND1 gene, which is a recognized human oncogene [35]. CCND1 amplification and overexpression are involved in breast cancer, lung cancer, melanoma and oral squamous cell carcinoma. CCND2 or CCND3 amplification is rare compared to CCND1 amplification [36, 37]. In breast cancer cells, cyclin D expression is enhanced by ligands or mutant activated estrogen receptors, which bind directly to the CCND1 promoter [26]. Estrogen can modulate mitosis by using cyclin D1 as one of its target genes [35]. In addition, the canonical RAS-RAF-MEK-ERK pathway and heightened activity of the HER2-PI3K-AKT axis also play a significant role in regulating cyclin D1 gene expression $[38,39]$. In theory, overexpression of cyclin D1 can induce the hyperactivation of CDK4 and CDK6 [40]. The expression of CDK4 is essential for the development of breast cancer, while the level of CDK6 is decreased in many breast tumors and in most breast tumor-derived cell lines [41, 42]. Yu $\mathrm{Q}$ et al. demonstrated that re-expression of human wild-type CDK4 endowed the cells with the ability to form tumors [7].

Table 1. Reported clinical trials investigating CDK4/6 inhibitors in breast cancer

\begin{tabular}{|c|c|c|c|c|c|c|c|}
\hline Trial name & Treatment arms & Setting & $\begin{array}{l}\text { Primary } \\
\text { endpoint }\end{array}$ & PFS & $\begin{array}{l}\text { ORR } \\
\text { (measurable } \\
\text { disease) }\end{array}$ & $\begin{array}{l}\text { CBR } \\
\text { (intention-to-treat } \\
\text { population) }\end{array}$ & G3/G4 adverse events ( $\geq 2 \%)$ \\
\hline $\begin{array}{l}\text { PALOMA-1/TRIO-18 } \\
{[56,57]}\end{array}$ & $\begin{array}{l}\text { 1.Palbociclib + } \\
\text { letrozole } \\
\text { 2. Letrozole }\end{array}$ & 1st line & PFS & $\begin{array}{l}\text { 1. } 20.2 \text { months } \\
\text { 2. } 10.2 \text { months } \\
\text { (HR } 0.488 ; 95 \% \\
\text { CI } 0.319-0.748 \\
\text { p }=0.0004)\end{array}$ & $\begin{array}{l}1.55 \%(95 \% \\
\text { CI } 43-68) \\
2.39 \%(95 \% \\
\text { CI } 28-52)\end{array}$ & $\begin{array}{l}1.81 \%(95 \% \mathrm{CI} \\
71-89) \\
2.58 \%(95 \% \mathrm{CI} \\
47-69)\end{array}$ & $\begin{array}{l}54 \% \text { neutropenia, } 19 \% \text { leukopenia, } 6 \% \text { anaemia, } 4 \% \\
\text { fatigue, } 4 \% \text { diarrhoea, } 2 \% \text { nausea, } 2 \% \\
\text { thrombocytopenia, } 2 \% \text { nausea, } 2 \% \text { dyspnoea, } 2 \% \\
\text { bone pain }\end{array}$ \\
\hline $\begin{array}{l}\text { PALOMA-2 } \\
{[59]}\end{array}$ & $\begin{array}{l}\text { 1.Palbociclib }+ \\
\text { letrozole } \\
\text { 2.Placebo }+ \\
\text { letrozole }\end{array}$ & 1st line & PFS & $\begin{array}{l}\text { 1. } 24.8 \text { months } \\
\text { 2. } 14.5 \text { months } \\
\text { (HR 0.58; } 95 \% \text { CI } \\
0.46-0.72 ; \\
\text { p<0.001) }\end{array}$ & $\begin{array}{l}1.55 \%(95 \% \\
\text { CI } 49.9-60.7) \\
2.44 \%(95 \% \\
\text { CI } 36.9-52.2)\end{array}$ & $\begin{array}{l}\text { 1. } 85 \%(95 \% \mathrm{CI} \\
81.2-88.1) \\
2.70 \%(95 \% \mathrm{CI} \\
63.8-76.2)\end{array}$ & $\begin{array}{l}66 \% \text { neutropenia, } 25 \% \text { leukopenia, } 5 \% \text { anaemia, } 2 \% \\
\text { febrile neutropenia, } 2 \% \text { fatigue, } 2 \% \text { asthenia, } 2 \% \\
\text { thrombocytopenia }\end{array}$ \\
\hline $\begin{array}{l}\text { PALOMA-3 } \\
\text { [61] }\end{array}$ & $\begin{array}{l}\text { 1.Palbociclib }+ \\
\text { fulvestrant } \\
\text { 2.Placebo }+ \\
\text { fulvestrant }\end{array}$ & 2nd line & PFS & $\begin{array}{l}\text { 1. } 9.5 \text { months } \\
\text { 2. } 4.6 \text { months } \\
\text { (HR } 0.46 ; 95 \% \text { CI } \\
0.36-0.59 ; \\
\text { p<0.0001) }\end{array}$ & $\begin{array}{l}\text { 1. } 25 \%(95 \% \\
\text { CI } 19.6-30.2) \\
2.11 \%(95 \% \\
\text { CI } 6.2-17.3)\end{array}$ & $\begin{array}{l}\text { 1. } 67 \%(95 \% \mathrm{CI} \\
61.3-71.5) \\
2.40 \%(95 \% \mathrm{CI} \\
32.3-47.3)\end{array}$ & $\begin{array}{l}65 \% \text { neutropenia, } 28 \% \text { leukopenia, } 3 \% \text { anaemia, } 3 \% \\
\text { thrombocytopenia, 3\% increased AST, } 2 \% \\
\text { increased ALT, } 2 \% \text { fatigue, } 2 \% \text { infections, } 2 \% \\
\text { hypertension }\end{array}$ \\
\hline $\begin{array}{l}\text { MONALEESA-2 } \\
{[14,68]}\end{array}$ & $\begin{array}{l}\text { 1. Ribociclib + } \\
\text { letrozole } \\
\text { 2. Placebo + } \\
\text { letrozole }\end{array}$ & 1st line & PFS & $\begin{array}{l}\text { 1. } 25.3 \text { months } \\
\text { 2. } 16.0 \text { months } \\
\text { (HR 0.56; } 95 \% \text { CI } \\
0.43-0.72 ; \\
\text { p<0.001) }\end{array}$ & $\begin{array}{l}1.53 \%(95 \% \\
\text { CI } 46.6-58.9) \\
2.37 \%(95 \% \\
\text { CI } 31.1-43.2)\end{array}$ & $\begin{array}{l}1.80 \%(95 \% \mathrm{CI} \\
75.3-84.0) \\
2.73 \%(95 \% \mathrm{CI} \\
68.0-77.5)\end{array}$ & $\begin{array}{l}59 \% \text { neutropenia, } 21 \% \text { leukopenia, } 9 \% \text { increased } \\
\text { ALT, } 6 \% \text { increased AST, } 4 \% \text { infections, } 4 \% \\
\text { vomiting, } 2 \% \text { fatigue, } 2 \% \text { nausea, } 2 \% \text { back pain }\end{array}$ \\
\hline $\begin{array}{l}\text { MONALEESA-3 } \\
{[70]}\end{array}$ & $\begin{array}{l}\text { 1. Ribociclib + } \\
\text { fulvestrant } \\
\text { 2. Placebo }+ \\
\text { fulvestrant }\end{array}$ & $\begin{array}{l}\text { 1st and } \\
\text { 2nd line }\end{array}$ & PFS & $\begin{array}{l}\text { 1. } 20.5 \text { months } \\
2.12 .8 \text { months } \\
\text { (HR 0.593; } 95 \% \\
\text { CI 0.48-0.73; } \\
\text { P<0.001) }\end{array}$ & $\begin{array}{l}1.41 \%(95 \% \\
\text { CI } 35.9-45.8) \\
2.29 \%(95 \% \\
\text { CI } 22.1-35.3)\end{array}$ & $\begin{array}{l}\text { 1. } 70 \%(95 \% \mathrm{CI} \\
66.2-74.3) \\
2.63 \%(95 \% \mathrm{CI} \\
56.7-68.9)\end{array}$ & $\begin{array}{l}53 \% \text { neutropenia, } 14 \% \text { leukopenia, } 6.6 \% \text { increased } \\
\text { ALT }\end{array}$ \\
\hline $\begin{array}{l}\text { MONALEESA-7 } \\
{[71]}\end{array}$ & $\begin{array}{l}\text { 1. Ribociclib }+ \\
\text { tamoxifen or NSAI } \\
+ \text { goserelin } \\
\text { 2. Placebo }+ \\
\text { tamoxifen or NSAI } \\
+ \text { goserelin }\end{array}$ & 1st line & PFS & $\begin{array}{l}\text { 1. } 23.8 \text { months } \\
\text { 2. } 13.0 \text { months } \\
\text { (HR } 0.55 ; 95 \% \text { CI } \\
0.44-0.69 ; \\
\text { p<0.0001) }\end{array}$ & $\begin{array}{l}1.51 \%(95 \% \\
\text { CI } 45-57) \\
2.36 \%(95 \% \\
\text { CI } 31-42)\end{array}$ & $\begin{array}{l}\text { 1. } 79 \%(95 \% \mathrm{CI} \\
75-84) \\
2.70 \%(95 \% \mathrm{CI} \\
65-75)\end{array}$ & $\begin{array}{l}61 \% \text { neutropenia, } 14 \% \text { leukopenia, } 5 \% \text { increased } \\
\text { ALT, } 4 \% \text { increased AST 3\% anaemia, 3\% } \\
\text { hypertension }\end{array}$ \\
\hline $\begin{array}{l}\text { MONARCH-1 } \\
\text { [73] }\end{array}$ & Abemaciclib & $\begin{array}{l}\text { 2nd line } \\
\text { and plus }\end{array}$ & ORR & $\begin{array}{l}6.0 \text { months }(95 \% \\
\text { CI } 4.2-7.5)\end{array}$ & $\begin{array}{l}19.7 \%(95 \% \text { CI } \\
13.3-27.5)\end{array}$ & $\begin{array}{l}42.4 \%(95 \% \text { CI } \\
33.9-51.3)\end{array}$ & $\begin{array}{l}28 \% \text { leucopenia, } 27 \% \text { neutropenia, } 20 \% \text { diarrhea, } \\
13 \% \text { fatigue, } 5 \% \text { nausea, } 5 \% \text { hypokalemia, } 4 \% \\
\text { increased ALT, 3\% decreased appetite, } 3 \% \\
\text { hyponatremia, } 2 \% \text { abdominal pain, } 2 \% \\
\text { thrombocytopenia }\end{array}$ \\
\hline $\begin{array}{l}\text { MONARCH- } 2 \\
{[74]}\end{array}$ & $\begin{array}{l}\text { 1. Abemaciclib + } \\
\text { fulvestrant } \\
\text { 2. Placebo }+ \\
\text { fulvestrant }\end{array}$ & 2nd line & PFS & $\begin{array}{l}\text { 1. } 16.4 \text { months } \\
\text { 2. } 9.3 \text { months } \\
\text { (HR } 0.553 ; 95 \% \\
\text { CI 0.449-0.681; } \\
\text { p<0.001) }\end{array}$ & $\begin{array}{l}\text { 1. } 48 \%(95 \% \\
\text { CI } 42.6-53.6) \\
\text { 2. } 21 \%(95 \% \\
\text { CI } 15.1-27.6)\end{array}$ & $\begin{array}{l}1.72 \%(95 \% \mathrm{CI} \\
68.0-76.4) \\
2.56 \%(95 \% \mathrm{CI} \\
49.5-62.6)\end{array}$ & $\begin{array}{l}27 \% \text { neutropenia, } 13 \% \text { diarrhoea, } 9 \% \text { leukopenia, } \\
7 \% \text { anaemia, } 4 \% \text { increased ALT, } 3 \% \text { fatigue, } 3 \% \\
\text { nausea, } 3 \% \text { thrombocytopenia, } 3 \% \text { dyspnoea, } 3 \% \\
\text { abdominal pain, } 2 \% \text { increased AST }\end{array}$ \\
\hline $\begin{array}{l}\text { MONARCH- } 3 \\
{[76]}\end{array}$ & $\begin{array}{l}\text { 1. Abemaciclib + } \\
\text { NSAI } \\
\text { 2. Placebo + NSAI }\end{array}$ & 1st line & PFS & $\begin{array}{l}\text { 1. } 28.18 \text { months } \\
\text { 2. } 14.76 \text { months } \\
\text { (HR } 0.540 ; 95 \% \\
\text { CI } 0.418-0.698 ; \\
\mathrm{p}=0.000002)\end{array}$ & $\begin{array}{l}\text { 1. } 61 \%(95 \% \\
\text { CI } 55.2-66.9) \\
\text { 2. } 46 \%(95 \% \\
\text { CI } 37.0-53.9)\end{array}$ & $\begin{array}{l}1.78 \%(95 \% \mathrm{CI} \\
73.6-82.5) \\
2.72 \%(95 \% \mathrm{CI} \\
64.6-78.4)\end{array}$ & $\begin{array}{l}24 \% \text { neutropenia, } 10 \% \text { diarrhea, } 9 \% \text { leucopenia, } 7 \% \\
\text { anemia, } 6 \% \text { increased ALT, } 4 \% \text { increased AST, } 2 \% \\
\text { blood creatinine increased }\end{array}$ \\
\hline
\end{tabular}

Abbreviations: PFS: progression-free survival; ORR: objective response rate; CBR: clinical benefit rate; HR: hazard ratio; CI: confidence interval; NSAI: non-steroidal aromatase inhibitors; AST: aspartate aminotransferase; ALT: increased alanine aminotransferas. 
The effects of CDK4/ 6 inhibitors are dependent on the presence of a functional RB protein. CDK4/6 inhibitors bind to the ATP-binding pocket existed in protein kinases, and thereby block downstream CDK4/6-mediated phosphorylation of $\mathrm{Rb}$ [17]. Unphosphorylated $\mathrm{Rb}$ still binds to E2F in an inactive complex, which results in the loss of genes that favor cell cycle progression. In this way, cells are arrested at the G1-S checkpoint and impossible to entry cell division [43]. In vivo trials, palbociclib caused a sustained suppression of tumor $\mathrm{Rb}$ phosphorylation, and exhibited significant antitumor efficacy that arrested Rb-positive tumors exclusively in G1, including Rb-positive breast cancer [44]. In addition, synergistic activity between cell cycle and anti-estrogen therapies had been observed in breast cancer cell lines [43]. As it was specifically in S phase that antiestrogens repress transcription of several ER target genes, an increase in apoptosis was observed when S phase blocked cells were treated with endocrine therapy compared with non-arrested cells. And the use of endocrine therapy in the $S$ phase led to a decrease in cell survival, which was associated with a significant reduction in cyclin D1 transcription [45, 46]. Published preclinical studies also supported the synergistic activity between palbociclib and endocrine therapy. Furthermore, palbociclib could reverse acquired resistance to anti-hormone therapy [13].

\section{Current status of CDK4/6 inhibitors}

Over the past few decades, we have witnessed tremendous progress in developing new and effective therapies, particularly through diverting tumor cells from a proliferation phenotype towards a non-division state. According to the important role of CDK4/6 in cell cycle regulation, CDK4/6 inhibitors are the most attractive findings. Prior experience with relatively non-selective pan-CDK inhibitors has led to limited clinical activity and poor safety [47, 48]. Highly selective oral CDK4/6 inhibitors palbociclib, ribociclib and abemaciclib can inhibit the proliferation of Rb-positive tumor cells and show dose-dependent growth inhibition in ER-positive breast cancer models $[47,48]$. All three drugs are small-molecule, ATP-competitive drugs, which bind to the ATP cleft of CDK4 and CDK6. However, abemaciclib buries two fluorine atoms against the back wall of the ATP-binding pocket and appears to bind more readily to the ATP cleft. On the other hand, it forms a hydrogen bond with a catalytic residue (Lys43) that is conserved among kinases, suggesting it binds with less selectivity than ribociclib and palbociclib [49].

Preclinical and clinical studies have shown CDK4/6 inhibitors' efficacy in HR-positive breast cancers. Their cooperative data was the basis for designing clinical trials in ER-positive breast cancers [50]. By blocking the aromatase enzyme, the third-generation aromatase inhibitors (AIs, anastrozole, letrozole and exemstane) are initially effective in the treatment of ER-positive tumors. However, de novo and acquired resistance remains a barrier to long-lasting clinical responses, particularly in the advanced disease [51, 52]. The selective estrogen receptor modulators (SERMs, tamoxifen, toremifene) and selective estrogen receptor downregulators (SERDs, fulvestrant) also face the drug resistance problem [51, 52]. One of the key features of CDK4/6 inhibitors is inhibition of cell proliferation in breast cancer cells that have developed resistance to endocrine therapy [52]. Combination therapies of CDK4/6 inhibitors with endocrine therapy (exemestane) and everolimus [an inhibitor of mTOR (mammalian target of rapamycin) signaling pathway] have shown significant clinical benefit [53]. The clinical trials mentioned in this section are summarized in Table 1. Furthermore, luminal androgen receptor (LAR) subtype of triple negative breast cancer (TNBC) was highly sensitive to CDK4/6 inhibitors, while basal-like TNBC was resistant. Therefore, CDK4/6 inhibitors may be considered as a novel therapeutic approach for TNBC [54].

\subsection{Palbociclib}

Palbociclib is the first CDK4/6 inhibitor to be introduced into clinical practice. It is not only a highly selective inhibitor of CDK4/6, but also equally effective for CDK4 and CDK6. Its peak concentration is between 6 and 12 hours and reaches a stable state within 8 days [55].

The PALOMA-1/TRIO-18 trial was a randomized phase 2 trial designed to evaluate the addition of palbociclib to letrozole therapy in patients who had received no prior treatment for ER-positive, HER2-negative advanced breast cancer (ABC). The combination therapy significantly improved progression-free survival (PFS) compared with single-agent letrozole [20.2 versus 10.2 months, hazard ratio (HR) 0.488, $\mathrm{p}=0.0004][53,56,57]$. Based on the results of PALOMA-1 trial, the FDA approved palbociclib (Ibrance) for use in combination with letrozole for the treatment of postmenopausal women with ER-positive, HER2-negative $\mathrm{ABC}$ as the first-line therapy for their metastatic disease, on February 3, $2015[56,58]$.

Then the PALOMA-2 phase 3 trial confirmed the clinical activity of palbociclib plus letrozole. The median PFS was 24.8 months in the combination therapy, as compared with 14.5 months in the placebo plus letrozole group (HR 0.58, p<0.001) [59]. At the 
same time, 125 patients were enrolled in the QT interval corrected for heart rate (QTc) evaluation substudy by using Fridericia's correction (QTcF), Bazett's correction (QTcB), and a studyspecific correction factor (QTcS). This study demonstrated that when palbociclib administered with letrozole at the recommended therapeutic dosing regimen, QTc prolongation $(<480 \mathrm{~ms})$ was not a safety concern for palbociclib [60].

Additionally, in the PALOMA-3 randomized phase 3 trial, patients were randomly assigned 2:1 to fulvestrant plus palbociclib or placebo. These patients were hormone receptor (HR)-positive, HER2-negative $A B C$ patients who had relapsed or progressed during previous endocrine therapy in any menopausal status. Median PFS was 9.5 months in the fulvestrant plus palbociclib group and 4.6 months in the fulvestrant plus placebo group (HR 0.46, $\mathrm{p}<0.0001)$ [61]. On February 19, 2016, the FDA approved palbociclib (Ibrance) for use in combination with fulvestrant for the treatment of women with HR-positive, HER2-negative advanced or metastatic breast cancer $(\mathrm{MBC})$ in the second-line setting. The approval was based on the results of PALOMA-3 trial [61, 62].

Based on these long-term safety analyses of three randomized phase II and III studies (PALOMA1, 2, 3), palbociclib plus endocrine therapy has not shown specific cumulative or delayed toxicities to HR-positive, HER2-negative $A B C$, supporting the ongoing investigation of palbociclib plus endocrine therapy in early breast cancer (NCT02513394) [63]. The PALLAS (NCT02513394) is a randomized phase III trial of palbociclib with standard adjuvant endocrine therapy versus standard adjuvant endocrine therapy alone for HR-positive, HER2-negative early breast cancer. Primary results are expected in 2020 [64]. Another phase III trials, PENELOPE-B (NCT01864746), is designed to demonstrate that in the background of standard anti-hormonal therapy palbociclib provides superior invasive disease-free survival (iDFS) compared to placebo in premenopausal and postmenopausal women with HR-positive, HER2-normal early breast cancer at high risk of relapse after showing less than pathological complete response to neoadjuvant taxane-containing chemotherapy. Primary results are expected in December 2020 [64].

\subsection{Ribociclib}

Ribociclib is another rapidly absorbed inhibitor of CDK4/6, reaching maximal concentration at 3.0-5.0 hours [65]. The ribociclib monotherapy dose escalation study (NCT01237236) declared the recommended phase II dose $600 \mathrm{mg} / \mathrm{d}$ on 21-of-28-d schedules and the maximum tolerated dose as 900 , among 128 patients with $\mathrm{Rb}+$ solid advanced tumors and lymphomas, including 18 breast cancer patients [66].

In MONALEESA-1, the phase II study, postmenopausal women with HR-positive, HER2-negative early breast cancer received letrozole with or without ribociclib. The ribociclib plus letrozole combination was well tolerated and no grade $3 / 4$ adverse events were observed after treatment [67].

MONALEESA-2 was a phase 3 randomized, double-blind, placebo-controlled trial. 668 postmenopausal HR-positive and HER2-negative $A B C$ patients who had not received prior treatment were randomized 1:1 to receive ribociclib plus letrozole or placebo plus letrozole [68]. As compared to placebo, the addition of ribociclib improved PFS from 16 months to 25.3 months (HR 0.56, p<0.001) [14, 68]. Based on these data, FDA approved ribociclib (Kisquali) in combination with letrozole for the first-line treatment of postmenopausal women with HR-positive, HER2-negative ABC or MBC on March 13, $2017[64,69]$.

The MONALEESA-3 phase 3 trial was intended for postmenopausal women with HR-positive, HER2-negative $A B C$ to receive ribociclib or placebo with fulvestrant. The median PFS was 20.5 months in the ribociclib arm versus 12.8 months in the placebo arm (HR, 0.593, p<0.001) [70]. On July 18, 2018, ribociclib (Kisquali) was also approved by FDA in combination with fulvestrant for the treatment of postmenopausal women with HR-positive, HER2-negative $A B C$ or $M B C$, as first-line or second-line therapy on the basis of MONALEESA-3 trial [64].

Recently, the results of the phase III MONALEESA-7 trial were presented. All women with HR-positive, HER2-negative $A B C$ in the study received ovarian function suppression together with oral endocrine therapy (tamoxifen or an aromatase inhibitor) plus ribociclib or not [14]. Median PFS was 23.8 months in the ribociclib group versus 13.0 months in the placebo group (HR 0.55, $\mathrm{p}<0.0001$ ). OS results outcomes were immature, with 89 deaths at the end of the data [71].

\subsection{Abemaciclib}

Abemaciclib is also a highly selective inhibitor of CDK4/6, and may have more complex pharmacological functions, including an effective CDK9 inhibition [49]. The breast cancer cell lines treated with LY2835219 showed a concentrationdependent inhibition of $\mathrm{pRb}$, and corresponding arrest of cells in G1 phase, which inhibited proliferation and led to decreased cell number [72]. 
The first phase II study to report single-agent activity of abemaciclib was MONARCH-1 trial, for heavily treated ER-positive, HER2-negative MBC patients. The primary endpoint of ORR was $19.7 \%$, with an observed clinical benefit rate of $42.4 \%$. The median PFS was 6.0 months [73].

MONARCH 2 was a phase III study of 669 patients with HR-positive, HER2-negative ABC who had progressed during neoadjuvant or adjuvant endocrine therapy. Patients were randomized 2:1 to receive abemaciclib or placebo and fulvestrant. Median PFS was 16.4 months in the abemaciclib plus fulvestrant arm versus 9.3 months in the fulvestrant arm [74]. Based on MONARCH 2 trial results, on the September 28, 2017, the FDA approved abemaciclib (Verzenio) in combination with fulvestrant in patients with HR-positive, HER2-negative $\mathrm{ABC}$ or MBC as second line therapy. On the same date, in the view of the MONARCH-1 trial results, abemaciclib (Verzenio) also approved by FDA as a monotherapy in patients with HR-positive, HER2-negative $\mathrm{ABC}$ or MBC as second or plus therapy in the metastatic setting [64, 75].

MONARCH 3 was a randomized phase III trial. 493 HR-positive, HER2-negative ABC patients who had not received prior treatment, were randomized 2:1 to receive abemaciclib plus anastrozole or letrozole versus placebo plus anastrozole or letrozole. The abemaciclib arm had a significantly longer median PFS than the placebo arm (28.18 versus 14.76 months) [76]. On August 17, 2018, FDA approved abemaciclib (Verzenio) in combination with an aromatase inhibitor as the treatment of postmenopausal women with HR-positive, HER2-negative $\mathrm{ABC}$ or $\mathrm{MBC}$ in the first line, given the results of the MONARCH 3 trial $[64,75]$.

\section{Mechanisms of resistance and combined treatment to alleviate drug resistance}

CDK4/6 inhibitors are becoming increasingly common in HR-positive, HER2-negative metastatic breast cancer patients and will certainly continue to increase in the future. However, their cytostatic effects are limited by primary and acquired resistance. Currently, there are lots of preclinical data about the mechanisms of de novo and acquired resistance to CDK4/ 6 inhibitors in breast cancer, but little has been demonstrated in clinical settings [77].

\subsection{Polyclonal RB I mutations and Loss of Rb function}

The effect of CDK4/6 inhibitors on inhibiting tumor cell growth is achieved by blocking the phosphorylation of $\mathrm{Rb}$ in the low nanomolar range
[13]. CDK4/ 6 inhibitors have been demonstrated to be effective against a variety of human Rb-positive tumors, including breast cancer [77]. In human breast cancer cell lines cultured in vitro to investigate the effects of palbociclib, higher levels of RB1 and $C C N D 1$, and lower levels of CDKN2A were found in the sensitive group [13]. However, most Rb-negative tumor cells were resistant to CDK4/6 inhibitors [77]. Direct analyses of primary tumors reported loss of $\mathrm{Rb}$ function in $20 \%$ to $35 \%$ of breast cancers. Considering the distribution of this direct inactivation, $\mathrm{Rb}$ inactivation may be a parameter leading to breast cancer heterogeneity [78].

In breast cancer cell lines, chronic loss of $\mathrm{Rb}$ has been associated with the development of a CDK4/6 inhibitor-resistant state [79]. The same result was also found in explants derived from human breast tumors [80]. To directly explore the functional consequences of $R b$, knockdown experiments were performed in immortalized mammary epithelia and breast cancer models. The results showed that palbociclib inhibited cell-cycle progression of normal human breast epithelial cells, and its activity mainly occurred through $\mathrm{Rb}$-mediated $\mathrm{E} 2 \mathrm{~F}$ repression [79]. In the following tumor cell lines, such as MDA-MB-231 and more significant levels in MCF-7 cells, Rb deficiency produced a very significant growth advantage in the presence of palbociclib, which had been observed to increase levels of E2F-target genes cyclins A and E [79]. These analyses indicated that the cells depended on alternative compensatory signaling pathways for their survival, which function independently of CDK4/ 6 activity, leading to treatment resistance [79].

Studies had shown that acquired mutation in $R B 1$ induced resistance to CDK4/ 6 inhibitor in PDX (from patients with ER-positive breast cancer). After 40 days of ribociclib treatment, tumors began to reproduce under drug stress. Compared to PDX244, which was sensitive to CDK4/6 inhibitors, western blot analysis showed that 4 of 7 CDK4/6-acquired resistant tumors had decreased levels of $\mathrm{pRb}$ protein and the E2F target cyclin E2 was continuously expressed. The genomic characteristics of PDX244LR1 (a serial passage of an LEE011-relapsed tumor) showed that RB1 frameshift mutation (RB1 p.M695fs*26) was obtained. In fact, loss of $R b$ expression was also detected in palbociclib-resistant cell lines in vitro [81]. In another study, authors derived a new signature of Rb loss-of-function (RBsig) to test whether this might identify palbociclib resistant and sensitive breast cancer cells. They found that the RBsig confirmed there was a poor prognosis for tumors with impaired $R b$ function. And the RBsig helped in discriminating between palbociclib resistant versus sensitive breast cancer cell lines [82]. 


\subsection{Hyperactivity of cyclin A/CDK2 or cyclin E/CDK2}

$\mathrm{CDK}$ 4/6-mediated $\mathrm{Rb}$ phosphorylation was first detected in mid-G1 phase after induction of cyclin D in mammalian cells entering the division cycle from G0, but prior to activation of cyclin E- and Adependent CDK2 [4]. ER-positive breast cancer cell lines were inhibited by palbociclib in culture, but they adapted very quickly as they allowed p27 degradation and subsequent increased in CDK2 activity, which would compensate for the loss of CDK4 activity and led to $\mathrm{Rb}$ phosphorylation and proliferation recovery [83]. Notably, all populations emerging from extended CDK4/ 6 inhibition possess increased CDK2 protein and/or loss of p21/p27. As an assembly factor, p27Kip1 is required both for the stabilization and the subsequent activation of cyclin D-CDK4 complex [84]. However, p27 must be activated on residue $\mathrm{Y} 88$ or $\mathrm{Y} 89$ to open or activate the complex. The activated effect of p27 depends on its phosphorylation status. Nonphosphorylated p27 is a stabilized form, which inhibits CDK2 activity as well as CDK4 [85].

Thus, ALT (the Brk-SH3 peptide) induction blocks p27 Y88 phosphorylation and then inhibits both CDK4 and CDK2, causing a potent and long-lasting cell-cycle arrest $[83,84]$. The combination of ALT and PD more potently reduced the activity of CDK2 and CDK4, synergized in cell arrest and increased senescence, and prevented cell recovery when the drug was removed [83]. And screening data showed that bone morphogenetic protein (BMP) 4 could inhibit cell growth and synergize with endocrine therapy and CDK4/6 inhibitors. By upregulation of p21, BMP4 enhanced sensitivity to CDK4/ 6 inhibitors in estrogen-resistant cells (Figure 2) [86]. Furthermore, transcriptomic features of BMP4 signaling predicted an improved biological response to the palbociclib combined with an aromatase inhibitor [86]. Fangchinoline is an alkaloid with cytotoxic, anti-inflammatory and antioxidant properties. In MCF-7 and MDA-MB-231 cells, the anti-proliferative activity of Fangchinoline was reflected in the downregulation of cyclin D1/D3/E and CDK2/4/6 (Figure 2) [87]. High expression levels of MMP-2, MMP-9 and NF- $\mathrm{\beta} \beta$ were associated to metastasis of breast tumors. In MDA-MB-231 cells, Fangchinoline inhibited the activation of AKT to increase the level of $\mathrm{I \kappa} \beta$ which inhibited the NF-k $\beta$ activity and reduced the levels of MMP-2 and MMP-9, thus to inhibit migration of the cells [88]. Given the Fangchinoline-induced cell growth inhibition and G1 cell-cycle arrest, combination therapy with CDK4/6 inhibitors may have progress in the next study.

\subsection{Upregulation of phosphorylated PDK1}

3-phosphoinositide-dependent protein kinase 1 (PDK1) is one of the key targets of PI3K signal downstream and also the key upstream kinase of AKT [89]. PDK1 phosphorylation is frequently increased and significantly associated with the breast cancer invasiveness. It is worth noting that moderate to high level of phosphorylation on PDK-1 (S241) is retained in high grades and metastatic breast tumors, indicating that phosphorylation and subsequent activation on PDK1 may contribute to aggressive metastasis of breast cancer [89].

Studies confirmed that, in ribociclib-resistant cell lines, the PI3K/PDK1 pathway mediated cell survival and proliferation by up-regulating of AKT and non-AKT targets of PDK1, all of which reached the peak in abnormal cell-cycle progression with emphasis on the presence of CDK4/6 [90]. Moreover, through increased CDK2/cyclin E/cyclin A, PDK1 promoted cell-cycle progression in CDK4/6-resistant cell lines [90]. Another study found that after chronic exposure to palbociclib, E2F-induced G1-S phase regulators such as cyclin E2 or CDK2 persisted, which failed to fully inhibit $\mathrm{Rb}$ phosphorylation, resulting in a slight increase in AKT phosphorylation [81]. CDK2/cyclin A2 acted as a major physiological kinase and had a role in controlling Akt phosphorylation and carcinogenesis. Notably, CDK2/cyclin A directly phosphorylated AKT1 on its carboxy (C)-terminal region in vitro [91]. Therefore, it can be demonstrated that early adaptation after exposure to CDK4/6 inhibition can be achieved by PI3K signaling through maintaining the expression of G1-S phase cyclin [81].

$\mathrm{PI} 3 \mathrm{~K} / \mathrm{mTOR}$ inhibitors induced synergistic anti-proliferative and pro-apoptotic effects by inhibiting both CDK4/6/Rb/myc and PI3K/mTOR signaling (Figure 2) [92]. Another study showed that cancer cells apoptosis after combined CDK $4 / 6$ and PI3K inhibition in vitro and patient-derived tumor xenograft (PDX) models. In addition, endocrine therapy, a triple combination of CDK4/6 and PI3K inhibition was more effective in triggering rapid tumor regression in the PDX model [81]. Michaloglou $C$ et al. found that when ER-positive breast cancer became resistant to CDK4/6 inhibitors, it still relied on E2F transcription to drive proliferation, which also confirmed the dependence of ER-positive breast cancer cells at this checkpoint [93]. At the same time, they demonstrated that inhibition of mTORC1/2 did lead to a decrease in cyclin $\mathrm{D} 1$ protein, $\mathrm{Rb}$ phosphorylation and E2F-mediated transcription, but did not directly affect ER function. In breast cancer cell lines and xenografts, the combination of mTORC1/2 inhibitors and CDK4/6 inhibitors had a deeper impact on E2F-dependent transcription, which 
was manifested in more persistent growth arrest and delayed drug-resistant episodes [93].

The RAS-RAF-MEK-ERK pathway is also an important pathway mediating the biological response of the epidermal growth factor receptor (EGFR), which regulates the growth and survival of breast cancer cells. Continuous ERK activation is a necessary condition for progression of G1 into S phase. And the ERK pathway induces cyclin D1 expression through its activation of the AP-1 complex [94, 95]. In KRAS mutant/PIK3CA wild-type cell lines (SW620 and H747), effective downregulation of cyclin D1 expression and cell arrest in G1 phase were detected under the presence of MEK inhibitors [96]. Based on these preclinical studies, several combination studies are now broadly interrogating the efficacy and safety of MEK and CDK4/ 6 inhibitors (Figure 2).

MicroRNAs (miRNAs) are small noncoding RNAs that regulate the translation of mRNA into proteins, and have been thought to be associated with specific molecular subtypes and clinicopathological characters in breast cancer, including miR-126 [97]. Significant downregulation of miR-126 was evident in breast cancer cell lines. Upregulated expression of miR-126 inhibited cell cycle transforming from G1/G0 to $S$ phase and inhibited insulin receptor substrate-1 (IRS-1) [98]. IRS-1, as an adaptor of IGF1R (insulin-like growth factor-1 receptor, which overexpressed in about $70 \%$ of breast cancer), played an important role in cell growth and proliferation mainly through activation of the downstream pathways such as PI3K-AKT and RAS-RAF-MAPK pathways [98, 99]. After identifying $14 \mathrm{miRNA} /$ drug combinations, miR-126 was the only miRNA that had significant enhanced effects in combination with CDK4/6 or PIK3CA inhibitors in vitro [100].

\subsection{Acquired CDK6 amplification}

After prolonged exposure to the CDK4/6 inhibitor abemaciclib, clones harboring CDK6 amplification emerged, resulting in a reduced response of breast cancer cells to the growth-inhibitory effects of CDK4/6 inhibitors [101]. Unexpectedly, overexpression of CDK4 had never been observed in these models, and further experiments showed that enforced overexpression of CDK4 did not promote drug resistance [101]. Yang C et al. speculated that inhibitor response was influenced by the partner cyclin or other components of the complex. CDK6 bound to cyclin D3 preferentially and the complex was more resistant than the cyclin D1-CDK4 complex. Above reasons raised the possibility that more powerful inhibitors for CDK6 might have greater clinical interest for acquired resistance patients [101].

\section{Methods to explore the mechanism of drug resistance}

Liquid biopsy is one of the revolutionary technologies involved in the detection and isolation of circulating tumor cells, circulating tumor DNA and exosomes, which extracted from plasma or other body fluids can serve as a source of genomic and proteomic information for cancer patients [102]. Circulating cell-free DNA has potential innovative applications in the diagnosis and management of cancer patients. Circulating blood contains millions of copies of the genome which is divided into short fragments, a small fraction of which is circulating tumor DNA (ctDNA) in cancer patients [103]. A study had identified first detectable multiple de novo somatic RB1 mutations in circulating tumor DNA (ctDNA) after 5, 8 and 13 months of exposure to CDK4/6 inhibitors (palbociclib, ribociclib), respectively, in three MBC patients. Their appearance dynamics suggested the mutations were related to the acquisition of resistant phenotype [104]. In a published case report, a patient with ER-positive breast cancer was treated with letrozole, everolimus, and palbociclib. After 11 months of treatment, RB1 mutation was caught in available ctDNA tests, which suggested an acquired resistance to palbociclib [105]. In another clinical study, HR-positive, HER2-negative patients received ctDNA evaluation at 3 months after chemotherapy treatment (except one who received chemotherapy plus letrozole). Patients (who had PFS $<3$ months) exhibited increased mutation frequencies in TERT, FAT1, RARA, and ERBB4, while patients (who had progression with PFS $>3$ months) had increased mutations in PIK3CA, TP53, NOTCH2, and MLL3. This suggested a distinct mechanism for drug resistance between HR-positive patients with different disease progression time [106].

Tim Forshew et al. applied tagged-amplicon deep sequencing (TAm-Seq) to detect abundant and rare mutations in circulating DNA in plasma of breast cancer patients. This sequencing method allowed it to monitor changes in tumor burden by sampling only patient plasma over time [103]. Quantification of allele fractions in plasma identified increased representation of mutant alleles associated with emergence of therapy resistance. In breast cancer patients, research results included an activating mutation in PIK3CA following treatment with paclitaxel, truncation mutation in MED1 (an ER co-activator involved in tamoxifen resistance) following treatment with tamoxifen and trastuzumab, and increased splicing mutation in GAS6 following treatment with lapatinib and capecitabine. These data demonstrated the possibility that exome-wide 
analysis of ctDNA to identify mutations associated with acquired drug resistance in breast cancer [107]. For another technique, cfDNA-targeted NGS had the potential to monitor targeted therapeutic responses through mutations and gene amplification, which could be used to monitor response and clonal dynamics during treatment in MBC [108]. In the next clinical studies, liquid biopsy of breast cancer patients treated with CDK4/6 inhibitors may be a crucial method for detecting the mechanisms of drug resistance.

\section{Combined treatment with anti-HER2 therapy or immunotherapy}

Studies have shown that HER2 dimerizes with other HER2-family partners and activate intracellular proliferative pathways, causing an aggressive clinical behavior [109]. Therefore, anti-HER2 therapy has led to dramatic improvements in survival in both early and advanced HER2-positive settings. Yet nearly all patients eventually progress on anti-HER2 therapy due to drug resistance [110]. In ER-positive, HER2-positive cancer cells, cyclin D1/CDK4 mediated resistance to anti-HER2 therapy, and CDK4/6 inhibitors were active both as single agents and in combination with trastuzumab in vitro studies (Figure 2) [111, 112]. Due to these preclinical studies and the great success in advanced ER-positive disease, studies combining CDK4/6 inhibitors and anti-HER2 therapy in "triple positive" patients are rapidly evolving [113]. Now there are already many trials investigating this combination both in the neoadjuvant and metastatic settings. In the PATINA trial (NCT02947685), ER-positive, HER2-positive patients will receive first-line induction chemotherapy with trastuzumab/pertuzumab, followed by a maintenance therapy: endocrine therapy/ trastuzumab/pertuzumab with or without palbociclib. The PATRICIA trial (NCT02448420) will include trastuzumab-resistant patients after 2-4 lines of anti-HER2 therapy, using different cohorts: ER-negative patients receive trastuzumab/palbociclib and ER-positive patients are randomized to receive trastuzumab/palbociclib with or without letrozole. Another advanced setting, monarcHER trial (NCT02675231) includes ER-positive, HER2-positive patients with at least 2 lines of previous therapy, who are randomized to receive trastuzumab/ chemotherapy, trastuzumab/abemaciclib or trastuzumab/abemaciclib/fulvestrant [114].

Interestingly, studies had shown that CDK4/6 inhibitors not only induced tumor cell cycle arrest, but also played a role in regulating mitogenic kinase signaling, inducing senescence and promoting anti-tumor immunity $[115,116]$. Thus, the prospects for CDK4/6 inhibitor-immunotherapy combinations are also promising. CDK4/6 inhibitors enhance antigen presentation, which results from suppression of $\mathrm{Rb}-\mathrm{E} 2 \mathrm{~F}$ axis followed by downregulation of DNA methyltransferase DNMT, induction of endogenous retroviral genes (ERVs), increased levels of double-stranded RNA (dsRNA) and type III

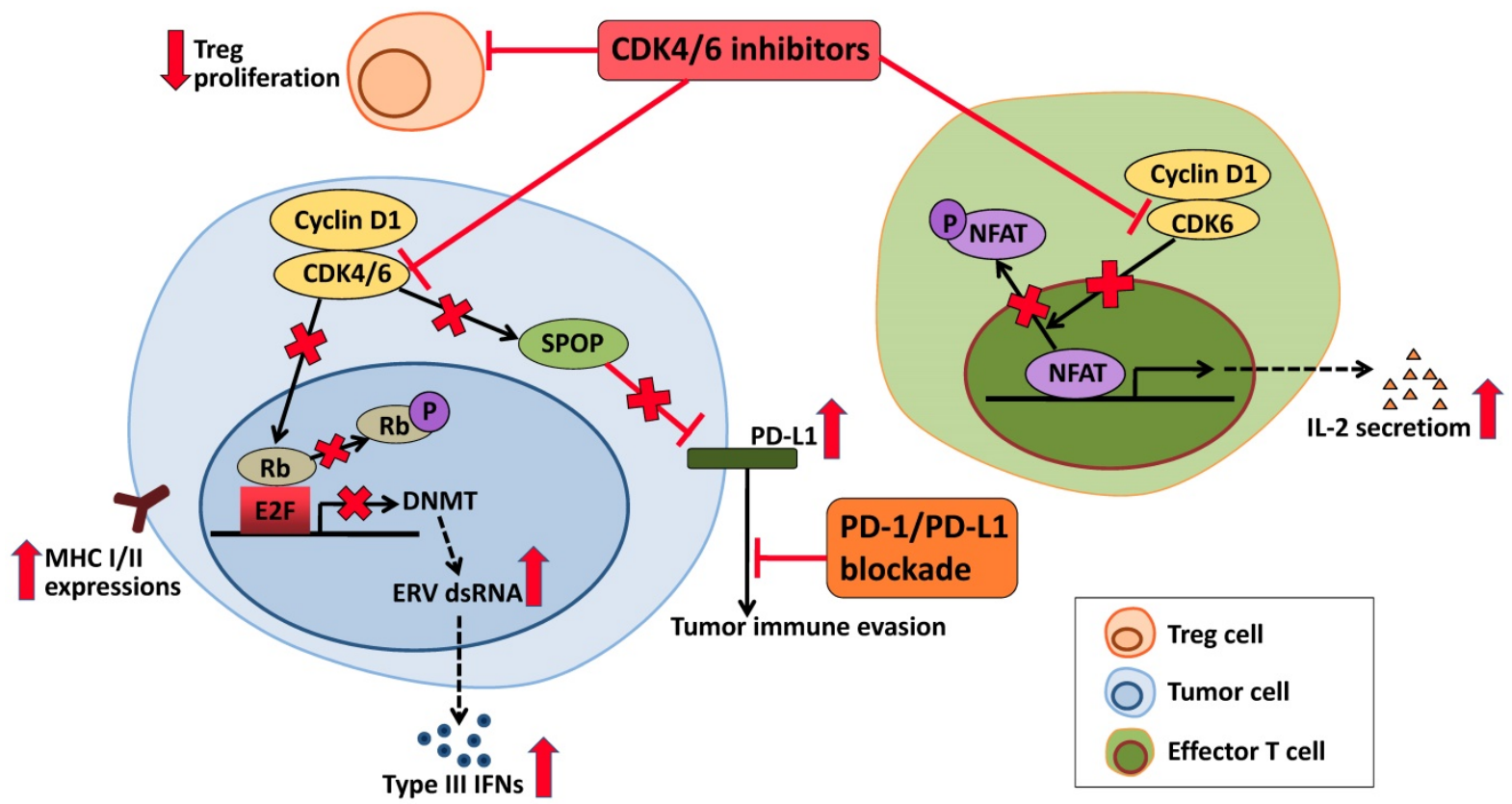

Figure 3. Effects of CDK4/6 inhibitors in anti-tumor immunity. In tumor cells, CDK4/6 inhibitor upregulates MHC I/II at tumor cell surface via reduced activity of the DNMT and induction of Type III IFNs, which may activate the anti-tumor activity of immune cells. In response to CDK4/6 inhibitor, the effector T cells increase the activity of NFAT and produce cytokines that can also enhance the anti-tumor immunity. Proliferation of Treg cells is suppressed by CDK4/6 inhibitor. While CDK4/6 inhibitor also upregulates the level of PD-L1. Therefore, CDK4/6 inhibitor may be combined synergically with PD-1/PD-L1 blockade in the clinic. 
interferon (IFNs) molecules [117]. Proliferation of immunesuppressive regulatory $\mathrm{T}$ cells (Tregs) is suppressed by CDK4/6 inhibitors in the tumor microenvironment [118]. In addition, CDK4/6 inhibitors can also enhance the anti-tumor immune response by upregulating the activity of NFAT and the level of cytokines (IL-2) in the effector T cells [118]. Cyclin D-CDK4 complex increases SPOP abundance, leading to reduction in the level of PD-L1. Therefore, in tumor cells, CDK4/6 inhibitors lower SPOP and promote expression of PD-L1, causing tumor immune evasion $[119,120]$. All of these activities of CDK4/6 inhibitors synergize with PD-L1 blockade to further enhance immune activation (Figure 3). Study has demonstrated that although anti-PD-L1 monotherapy had very modest effects, CDK $4 / 6$ inhibitors showed combinatorial benefit when combined with
anti-PD-L1 therapy [117]. A complete overview of the ongoing clinical trials is given in Table 2.

\section{Conclusions}

Because the CDK4/ 6 plays an important role in the development and progression of breast cancer, CDK4/ 6 inhibitors have revolutionized the treatment of metastatic breast cancer. In combination with endocrine therapies, CDK4/ 6 inhibitors have become a new standard of care for patients with ER-positive breast cancer. Current research on the resistance mechanisms of CDK4/6 inhibitors are only at the beginning stage. With the extensive application of CDK4/6 inhibitors in clinical practice, the resistance mechanisms will become a hot spot. More precise researches are needed to guide individualized treatment and combination with other drugs.

Table 2. Ongoing clinical trials in combination with anti-HER2 therapy or immunotherapy. ClinicalTrials.gov April 2019.

\begin{tabular}{|c|c|c|c|c|c|c|}
\hline $\begin{array}{l}\text { Clinical trials.gov } \\
\text { identifier }\end{array}$ & Phase & $\begin{array}{l}\text { Recruitment } \\
\text { status }\end{array}$ & Therapy & Breast tumor type & $\begin{array}{l}\text { Estimated } \\
\text { enrollment }\end{array}$ & Primary endpoint \\
\hline \multicolumn{7}{|l|}{ Palbociclib } \\
\hline NCT01976169 & IB & Recruiting & PD-0332991 + T-DM1 & HER2+ ABC & 17 & $\begin{array}{l}\text { - MTD } \\
\text { - DLT }\end{array}$ \\
\hline NCT03054363 & $\mathrm{IB} / \mathrm{II}$ & $\begin{array}{l}\text { Active, not } \\
\text { recruiting }\end{array}$ & Tucatinib + palbociclib + letrozole & $\begin{array}{l}\text { HR+/HER2+ locally advanced } \\
\text { unresectable or metastatic breast cancer }\end{array}$ & 25 & $\begin{array}{l}\text { - Phase I: AE } \\
\text { - Phase II: PFS }\end{array}$ \\
\hline NCT03709082 & $\mathrm{I} / \mathrm{II}$ & Recruiting & Palbociclib + letrozole + T-DM1 & Trastuzumab refractory ER+/HER2+ MBC & 62 & ORR \\
\hline NCT03304080 & $\mathrm{I} / \mathrm{II}$ & Recruiting & $\begin{array}{l}\text { Anastrozole }+ \text { palbociclib }+ \text { trastuzumab }+ \\
\text { pertuzumab }\end{array}$ & $\mathrm{HR}+/ \mathrm{HER} 2+\mathrm{MBC}$ & 36 & $\begin{array}{l}\text { - DLT } \\
\text { - MTD } \\
\text { - CBR }\end{array}$ \\
\hline $\begin{array}{l}\text { NCT02907918 } \\
\text { PALTAN }\end{array}$ & II & Recruiting & Palbociclib + letrozole + trastuzumab & Stage II-III ER+/HER2+ BC & 48 & pCR rate \\
\hline $\begin{array}{l}\text { NCT02448420 } \\
\text { PATRICIA }\end{array}$ & II & Recruiting & $\begin{array}{l}\text { 1. Palbociclib + trastuzumab } \\
\text { 2. Palbociclib + trastuzumab. }+ \text { letrozole }\end{array}$ & $\begin{array}{l}\text { Postmenopausal previously-treated locally } \\
\text { HER2+ ABC or MBC }\end{array}$ & 138 & PFS \\
\hline $\begin{array}{l}\text { NCT02530424 } \\
\text { NA-PHER2 }\end{array}$ & II & $\begin{array}{l}\text { Active, not } \\
\text { recruiting }\end{array}$ & $\begin{array}{l}\text { 1.Trastuzumab + pertuzumab + palbociclib } \\
\text { +fulvestrant } \\
\text { 2. Trastuzumab + pertuzumab + palbociclib }\end{array}$ & $\begin{array}{l}\text { Invasive unilateral non metastatic ER+/ } \\
\text { HER2+ BC }\end{array}$ & 102 & $\begin{array}{l}\text { - Serial measures of } \\
\text { Ki67, } \\
\text { - Serial measures of } \\
\text { apoptosis }\end{array}$ \\
\hline NCT02774681 & II & $\begin{array}{l}\text { Active, not } \\
\text { recruiting }\end{array}$ & Palbociclib + trastuzumab & HER2+ MBC with brain metastasis & 12 & $\begin{array}{l}\text { Radiographic } \\
\text { response rate in the } \\
\text { CNS }\end{array}$ \\
\hline $\begin{array}{l}\text { NCT03147287 } \\
\text { PACE }\end{array}$ & II & Recruiting & $\begin{array}{l}\text { 1. Fulvestrant } \\
\text { 2. Fulvestrant }+ \text { palbociclib } \\
\text { 3. Fulvestrant }+ \text { palbociclib }+ \text { avelumab }\end{array}$ & $\begin{array}{l}\text { HR+/HER2- MBC that has previously } \\
\text { stopped responding to prior palbociclib } \\
\text { and endocrine therapy. }\end{array}$ & 220 & PFS \\
\hline $\begin{array}{l}\text { NCT02947685 } \\
\text { PATINA }\end{array}$ & III & Recruiting & $\begin{array}{l}\text { 1. Palbociclib + trastuzumab/pertuzumab + } \\
\text { letrozole, anastrozole, exemstane or } \\
\text { fulvestratnt } \\
\text { 2.Trastuzumab/pertuzumab + letrozole, } \\
\text { anastrozole, exemstane or fulvestrant }\end{array}$ & $\mathrm{HR}+/ \mathrm{HER} 2+\mathrm{MBC}$ & 496 & PFS \\
\hline \multicolumn{7}{|l|}{ Ribociclib } \\
\hline NCT02657343 & $\mathrm{IB} / \mathrm{II}$ & Recruiting & $\begin{array}{l}\text { 1. Ribociclib + Trastuzumab } \\
\text { 2. Ribociclib + T-DM1 } \\
\text { 3. Ribociclib + Trastuzumab + fulvestrant }\end{array}$ & HER2+ ABC or MBC & 86 & $\begin{array}{l}- \text { MTD } \\
- \text { CBR }\end{array}$ \\
\hline \multicolumn{7}{|l|}{ Abemaciclib } \\
\hline NCT02057133 & IB & Recruiting & $\begin{array}{l}\text { Abemaciclib }+ \text { trastuzumab + pertuzumab } \\
\text { +loperamide dose escalation }\end{array}$ & $\mathrm{MBC}$ & 198 & $\begin{array}{l}\text { Number of } \\
\text { participants with } \mathrm{AE}\end{array}$ \\
\hline $\begin{array}{l}\text { NCT02675231 } \\
\text { monarcHER }\end{array}$ & II & $\begin{array}{l}\text { Active, not } \\
\text { recruiting }\end{array}$ & $\begin{array}{l}\text { 1. Abemaciclib }+ \text { trastuzumab }+ \text { fulvestrant } \\
\text { 2. Abemaciclib }+ \text { trastuzumab } \\
\text { 3. Trastuzumab + chemotherapy }\end{array}$ & HR+/ HER2+ locally ABC or MBC & 225 & PFS \\
\hline
\end{tabular}




\section{Acknowledgments}

The present study was supported by Central Guidance for Special Funds (2016007011) and Key Research Project of Liaoning (2018225076); Special Fund for Clinical Research of Wu Jieping Medical Foundation (320.6750.18541) and CSCO-Hengrui Cancer Research Foundation (Y-HR2018-362).

\section{Competing Interests}

The authors have declared that no competing interest exists.

\section{References}

1. Schwartz GK, Shah MA. Targeting the cell cycle: a new approach to cancer therapy. Journal of clinical oncology : official journal of the American Society of Clinical Oncology. 2005; 23: 9408-21.

2. Massague J. G1 cell-cycle control and cancer. Nature. 2004; 432: 298-306.

3. Brookes S, Gagrica S, Sanij E, Rowe J, Gregory FJ, Hara E, et al. Evidence for a CDK4-dependent checkpoint in a conditional model of cellular senescence. Cell cycle (Georgetown, Tex). 2015; 14: 1164-73.

4. Sherr CJ, Beach D, Shapiro GI. Targeting CDK4 and CDK6: From Discovery to Therapy. Cancer discovery. 2016; 6: 353-67.

5. Ingham M, Schwartz GK. Cell-Cycle Therapeutics Come of Age. Journal of clinical oncology : official journal of the American Society of Clinical Oncology. 2017; 35: 2949-59.

6. Yu Q, Geng Y, Sicinski P. Specific protection against breast cancers by cyclin D1 ablation. Nature. 2001; 411: 1017-21.

7. Yu Q, Sicinska E, Geng Y, Ahnstrom M, Zagozdzon A, Kong Y, et al. Requirement for CDK4 kinase function in breast cancer. Cancer cell. 2006; 9: 23-32.

8. Zhu S, Mott RT, Fry EA, Taneja P, Kulik G, Sui G, et al. Cooperation between Dmp1 loss and cyclin D1 overexpression in breast cancer. The American journal of pathology. 2013; 183: 1339-50.

9. Liu M, Liu H, Chen J. Mechanisms of the CDK4/6 inhibitor palbociclib (PD 0332991) and its future application in cancer treatment (Review). Oncology reports. 2018; 39: 901-11.

10. Benson C, White J, De Bono J, O'Donnell A, Raynaud F, Cruickshank C, et al. A phase I trial of the selective oral cyclin-dependent kinase inhibitor seliciclib (CYC202; R-Roscovitine), administered twice daily for 7 days every 21 days. British journal of cancer. 2007; 96: 29-37.

11. Collins I, Garrett MD. Targeting the cell division cycle in cancer: CDK and cell cycle checkpoint kinase inhibitors. Current opinion in pharmacology. 2005; 5: 366-73.

12. O'Leary B, Finn RS, Turner NC. Treating cancer with selective CDK4/6 inhibitors. Nature reviews Clinical oncology. 2016; 13: 417-30.

13. Finn RS, Dering J, Conklin D, Kalous O, Cohen DJ, Desai AJ, et al. PD 0332991 , a selective cyclin D kinase 4/6 inhibitor, preferentially inhibits proliferation of luminal estrogen receptor-positive human breast cancer cell lines in vitro. Breast cancer research : BCR. 2009; 11: R77.

14. Pernas S, Tolaney SM, Winer EP, Goel S. CDK4/6 inhibition in breast cancer: current practice and future directions. Therapeutic advances in medical oncology. 2018; 10: 1758835918786451

15. Oki T, Nishimura K, Kitaura J, Togami K, Maehara A, Izawa K, et al. A novel cell-cycle-indicator, mVenus-p27K-, identifies quiescent cells and visualizes G0-G1 transition. Scientific reports. 2014; 4: 4012.

16. Diehl JA. Cycling to cancer with cyclin D1. Cancer biology \& therapy. 2002; 1 : 226-31.

17. Asghar U, Witkiewicz AK, Turner NC, Knudsen ES. The history and future of targeting cyclin-dependent kinases in cancer therapy. Nature reviews Drug discovery $2015 ; 14: 130-46$

18. Baker SJ, Reddy EP. CDK4: A Key Player in the Cell Cycle, Development, and Cancer. Genes \& cancer. 2012; 3: 658-69.

19. Lim S, Kaldis P. Cdks, cyclins and CKIs: roles beyond cell cycle regulation. Development (Cambridge, England). 2013; 140: 3079-93.

20. Henley SA, Dick FA. The retinoblastoma family of proteins and their regulatory functions in the mammalian cell division cycle. Cell division. 2012; 7: 10 .

21. Narasimha AM, Kaulich M, Shapiro GS, Choi YJ, Sicinski P, Dowdy SF. Cyclin $\mathrm{D}$ activates the $\mathrm{Rb}$ tumor suppressor by mono-phosphorylation. eLife. 2014; 3 .

22. Giacinti C, Giordano A. RB and cell cycle progression. Oncogene. 2006; 25: 5220-7.

23. Coqueret O. Linking cyclins to transcriptional control. Gene. 2002; 299: 35-55.

24. Qie S, Diehl JA. Cyclin D1, cancer progression, and opportunities in cancer treatment. Journal of molecular medicine (Berlin, Germany). 2016; 94: 1313-26.
25. Gopinathan L, Tan SL, Padmakumar VC, Coppola V, Tessarollo L, Kaldis P. Loss of Cdk2 and cyclin A2 impairs cell proliferation and tumorigenesis. Cancer research. 2014; 74: 3870-9.

26. VanArsdale T, Boshoff C, Arndt KT, Abraham RT. Molecular Pathways: Targeting the Cyclin D-CDK4/6 Axis for Cancer Treatment. Clinical cancer research : an official journal of the American Association for Cancer Research. 2015; 21: 2905-10.

27. Shapiro GI. Cyclin-dependent kinase pathways as targets for cancer treatment. Journal of clinical oncology : official journal of the American Society of Clinical Oncology. 2006; 24: 1770-83.

28. Malumbres M, Barbacid M. Cell cycle, CDKs and cancer: a changing paradigm. Nature reviews Cancer. 2009; 9: 153-66.

29. Witkiewicz AK, Knudsen ES. Retinoblastoma tumor suppressor pathway in breast cancer: prognosis, precision medicine, and therapeutic interventions. Breast cancer research : BCR. 2014; 16: 207.

30. Evan GI, Vousden KH. Proliferation, cell cycle and apoptosis in cancer. Nature. 2001; 411: 342-8.

31. Buckley MF, Sweeney KJ, Hamilton JA, Sini RL, Manning DL, Nicholson RI, et al. Expression and amplification of cyclin genes in human breast cancer. Oncogene. 1993; 8: 2127-33.

32. Kim JK, Diehl JA. Nuclear cyclin D1: an oncogenic driver in human cancer. Journal of cellular physiology. 2009; 220: 292-6.

33. Casimiro MC, Velasco-Velazquez M, Aguirre-Alvarado C, Pestell RG. Overview of cyclins D1 function in cancer and the CDK inhibitor landscape: past and present. Expert opinion on investigational drugs. 2014; 23: 295-304.

34. Cancer Genome Atlas Network. Comprehensive molecular portraits of human breast tumours. Nature. 2012; 490: 61-70.

35. Peurala E, Koivunen P, Haapasaari KM, Bloigu R, Jukkola-Vuorinen A. The prognostic significance and value of cyclin D1, CDK4 and p16 in human breast cancer. Breast cancer research : BCR. 2013; 15: R5.

36. Musgrove EA, Caldon CE, Barraclough J, Stone A, Sutherland RL. Cyclin D as a therapeutic target in cancer. Nature reviews Cancer. 2011; 11: 558-72.

37. Santarius T, Shipley J, Brewer D, Stratton MR, Cooper CS. A census of amplified and overexpressed human cancer genes. Nature reviews Cancer. 2010; 10: 59-64.

38. Klein EA, Assoian RK. Transcriptional regulation of the cyclin D1 gene at a glance. Journal of cell science. 2008; 121: 3853-7.

39. Winston JT, Coats SR, Wang YZ, Pledger WJ. Regulation of the cell cycle machinery by oncogenic ras. Oncogene. 1996; 12: 127-34.

40. Deshpande A, Sicinski P, Hinds PW. Cyclins and cdks in development and cancer: a perspective. Oncogene. 2005; 24: 2909-15.

41. Jia Y, Domenico J, Swasey C, Wang M, Gelfand EW, Lucas JJ. Modulated expression of genes encoding estrogen metabolizing enzymes by G1-phase cyclin-dependent kinases 6 and 4 in human breast cancer cells. PloS one. 2014; 9: e97448

42. Tigan AS, Bellutti F, Kollmann K, Tebb G, Sexl V. CDK6-a review of the past and a glimpse into the future: from cell-cycle control to transcriptional regulation. Oncogene. 2016; 35: 3083-91.

43. Sammons SL, Topping DL, Blackwell KL. HR+, HER2- Advanced Breast Cancer and CDK4/ 6 Inhibitors: Mode of Action, Clinical Activity, and Safety Profiles. Current cancer drug targets. 2017; 17: 637-49.

44. Fry DW, Harvey PJ, Keller PR, Elliott WL, Meade M, Trachet E, et al. Specific inhibition of cyclin-dependent kinase $4 / 6$ by PD 0332991 and associated antitumor activity in human tumor xenografts. Molecular cancer therapeutics. 2004; 3: 1427-38.

45. Dalvai M, Bystricky K. Cell cycle and anti-estrogen effects synergize to regulate cell proliferation and ER target gene expression. PloS one. 2010; 5: e11011.

46. Butt AJ, McNeil CM, Musgrove EA, Sutherland RL. Downstream targets of growth factor and oestrogen signalling and endocrine resistance: the potential roles of c-Myc, cyclin D1 and cyclin E. Endocrine-related cancer. 2005; 12 Suppl 1: S47-59.

47. Xu H, Yu S, Liu Q, Yuan X, Mani S, Pestell RG, et al. Recent advances of highly selective CDK4/6 inhibitors in breast cancer. Journal of hematology \& oncology. 2017; 10: 97.

48. Spring L, Bardia A, Modi S. Targeting the cyclin D-cyclin-dependent kinase (CDK) 4/6-retinoblastoma pathway with selective CDK 4/6 inhibitors in hormone receptor-positive breast cancer: rationale, current status, and future directions. Discovery medicine. 2016; $21: 65-74$

49. Chen P, Lee NV, Hu W, Xu M, Ferre RA, Lam H, et al. Spectrum and Degree of CDK Drug Interactions Predicts Clinical Performance. Molecular cancer therapeutics. 2016; 15: 2273-81.

50. Kwapisz D. Cyclin-dependent kinase $4 / 6$ inhibitors in breast cancer: palbociclib, ribociclib, and abemaciclib. Breast cancer research and treatment. 2017; 166: 41-54

51. Fan W, Chang J, Fu P. Endocrine therapy resistance in breast cancer: current status, possible mechanisms and overcoming strategies. Future medicinal chemistry. 2015; 7: 1511-9.

52. Wardell SE, Ellis MI, Alley HM, Eisele $\mathrm{K}$, VanArsdale $\mathrm{T}$, Dann SG, et al Efficacy of SERD/SERM Hybrid-CDK4/6 Inhibitor Combinations in Models of Endocrine Therapy-Resistant Breast Cancer. Clinical cancer research : an official journal of the American Association for Cancer Research. 2015; 21: $5121-30$

53. de Groot AF, Kuijpers CJ, Kroep JR. CDK4/6 inhibition in early and metastatic breast cancer: A review. Cancer treatment reviews. 2017; 60: 130-8. 
54. Asghar US, Barr AR, Cutts R, Beaney M, Babina I, Sampath D, et al. Single-Cell Dynamics Determines Response to CDK4/6 Inhibition in Triple-Negative Breast Cancer. Clinical cancer research : an official journal of the American Association for Cancer Research. 2017; 23: 5561-72.

55. Morikawa A, Henry NL. Palbociclib for the Treatment of Estrogen Receptor-Positive, HER2-Negative Metastatic Breast Cancer. Clinical cancer research : an official journal of the American Association for Cancer Research. 2015; 21: 3591-6.

56. Finn RS, Crown JP, Lang I, Boer K, Bondarenko IM, Kulyk SO, et al. The cyclin-dependent kinase $4 / 6$ inhibitor palbociclib in combination with letrozole versus letrozole alone as first-line treatment of oestrogen receptor-positive, HER2-negative, advanced breast cancer (PALOMA-1/TRIO-18): a randomised phase 2 study. The Lancet Oncology. 2015; 16: 25-35.

57. Messina C, Cattrini C, Buzzatti G, Cerbone L, Zanardi E, Messina M, et al. CDK4/6 inhibitors in advanced hormone receptor-positive/HER2-negative breast cancer: a systematic review and meta-analysis of randomized trials. Breast cancer research and treatment. 2018; 172: 9-21.

58. Beaver JA, Amiri-Kordestani L, Charlab R, Chen W, Palmby T, Tilley A, et al. FDA Approval: Palbociclib for the Treatment of Postmenopausal Patients with Estrogen Receptor-Positive, HER2-Negative Metastatic Breast Cancer. Clinical cancer research : an official journal of the American Association for Cancer Research. 2015; 21: 4760-6.

59. Finn RS, Martin M, Rugo HS, Jones S, Im SA, Gelmon K, et al. Palbociclib and Letrozole in Advanced Breast Cancer. The New England journal of medicine. 2016; 375: 1925-36

60. Durairaj C, Ruiz-Garcia A, Gauthier ER, Huang X, Lu DR, Hoffman JT, et al. Palbociclib has no clinically relevant effect on the QTc interval in patients with advanced breast cancer. Anti-cancer drugs. 2018; 29: 271-80.

61. Cristofanilli M, Turner NC, Bondarenko I, Ro J, Im SA, Masuda N, et al. Fulvestrant plus palbociclib versus fulvestrant plus placebo for treatment of hormone-receptor-positive, HER2-negative metastatic breast cancer that progressed on previous endocrine therapy (PALOMA-3): final analysis of the multicentre, double-blind, phase 3 randomised controlled trial. The Lancet Oncology. 2016; 17: 425-39.

62. Walker AJ, Wedam S, Amiri-Kordestani L, Bloomquist E, Tang S, Sridhara R, et al. FDA Approval of Palbociclib in Combination with Fulvestrant for the Treatment of Hormone Receptor-Positive, HER2-Negative Metastatic Breast Cancer. Clinical cancer research : an official journal of the American Association for Cancer Research. 2016; 22: 4968-72.

63. Dieras V, Rugo HS, Schnell P, Gelmon K, Cristofanilli M, Loi S, et al. Long-term Pooled Safety Analysis of Palbociclib in Combination With Endocrine Therapy for HR+/HER2- Advanced Breast Cancer. Journal of the National Cancer Institute. 2019; 111: 419-30.

64. [Internet] US National Library of Medicine. Accessed March 2019. https://clinicaltrials.gov

65. Doi T, Hewes B, Kakizume T, Tajima T, Ishikawa N, Yamada Y. Phase I study of single-agent ribociclib in Japanese patients with advanced solid tumors. Cancer science. 2018; 109: 193-8.

66. Infante JR, Cassier PA, Gerecitano JF, Witteveen PO, Chugh R, Ribrag V, et al. A Phase I Study of the Cyclin-Dependent Kinase 4/6 Inhibitor Ribociclib (LEE011) in Patients with Advanced Solid Tumors and Lymphomas. Clinical cancer research : an official journal of the American Association for Cancer Research. 2016; 22: 5696-705.

67. Curigliano G, Gomez Pardo P, Meric-Bernstam F, Conte P, Lolkema MP, Beck JT, et al. Ribociclib plus letrozole in early breast cancer: A presurgical, window-of-opportunity study. Breast (Edinburgh, Scotland). 2016; 28: 191-8.

68. Hortobagyi GN, Stemmer SM, Burris HA, Yap YS, Sonke GS, Paluch-Shimon $\mathrm{S}$, et al. Ribociclib as First-Line Therapy for HR-Positive, Advanced Breast Cancer. The New England journal of medicine. 2016; 375: 1738-48.

69. [No authors listed]. Ribociclib Approved for Advanced Breast Cancer. Cancer Discovery. 2017; 7: Of3.

70. Slamon DJ, Neven P, Chia S, Fasching PA, De Laurentiis M, Im SA, et al. Phase III Randomized Study of Ribociclib and Fulvestrant in Hormone Receptor-Positive, Human Epidermal Growth Factor Receptor 2-Negative Advanced Breast Cancer: MONALEESA-3. Journal of clinical oncology : official journal of the American Society of Clinical Oncology. 2018; 36: 2465-72.

71. Tripathy D, Im SA, Colleoni M, Franke F, Bardia A, Harbeck N, et al. Ribociclib plus endocrine therapy for premenopausal women with hormone-receptor-positive, advanced breast cancer (MONALEESA-7): a randomised phase 3 trial. The Lancet Oncology. 2018; 19: 904-15.

72. Gelbert LM, Cai S, Lin X, Sanchez-Martinez C, Del Prado M, Lallena MJ, et al. Preclinical characterization of the CDK4/6 inhibitor LY2835219: in-vivo cell cycle-dependent/independent anti-tumor activities alone/in combination with gemcitabine. Investigational new drugs. 2014; 32: 825-37.

73. Dickler MN, Tolaney SM, Rugo HS, Cortes J, Dieras V, Patt D, et al. MONARCH 1, A Phase II Study of Abemaciclib, a CDK4 and CDK6 Inhibitor, as a Single Agent, in Patients with Refractory HR(+)/HER2(-) Metastatic Breast Cancer. Clinical cancer research : an official journal of the American Association for Cancer Research. 2017; 23: 5218-24.

74. Sledge GW, Jr., Toi M, Neven P, Sohn J, Inoue K, Pivot X, et al. MONARCH 2: Abemaciclib in Combination With Fulvestrant in Women With HR+/HER2Advanced Breast Cancer Who Had Progressed While Receiving Endocrine Therapy. Journal of clinical oncology : official journal of the American Society of Clinical Oncology. 2017; 35: 2875-84.
75. Corona SP, Generali D. Abemaciclib: a CDK4/6 inhibitor for the treatment of HR+/HER2- advanced breast cancer. Drug design, development and therapy. 2018; $12: 321-30$.

76. Johnston S, Martin M, Di Leo A, Im SA, Awada A, Forrester T, et al. MONARCH 3 final PFS: a randomized study of abemaciclib as initial therapy for advanced breast cancer. NPJ breast cancer. 2019; 5 : 5 .

77. Guarducci C, Bonechi M, Boccalini G, Benelli M, Risi E, Di Leo A, et al. Mechanisms of Resistance to CDK4/6 Inhibitors in Breast Cancer and Potential Biomarkers of Response. Breast care (Basel, Switzerland). 2017; 12: 304-8

78. Bosco EE, Knudsen ES. RB in breast cancer: at the crossroads of tumorigenesis and treatment. Cell cycle (Georgetown, Tex). 2007; 6: 667-71.

79. Dean JL, Thangavel C, McClendon AK, Reed CA, Knudsen ES. Therapeutic CDK4/6 inhibition in breast cancer: key mechanisms of response and failure. Oncogene. 2010; 29: 4018-32.

80. Dean JL, McClendon AK, Hickey TE, Butler LM, Tilley WD, Witkiewicz AK, et al. Therapeutic response to CDK4/6 inhibition in breast cancer defined by ex vivo analyses of human tumors. Cell cycle (Georgetown, Tex). 2012; 11: 2756-61

81. Herrera-Abreu MT, Palafox M, Asghar U, Rivas MA, Cutts RJ, Garcia-Murillas I, et al. Early Adaptation and Acquired Resistance to CDK4/6 Inhibition in Estrogen Receptor-Positive Breast Cancer. Cancer research. 2016; 76: 2301-13.

82. Malorni L, Piazza S, Ciani Y, Guarducci C, Bonechi M, Biagioni C, et al. A gene expression signature of retinoblastoma loss-of-function is a predictive biomarker of resistance to palbociclib in breast cancer cell lines and is prognostic in patients with ER positive early breast cancer. Oncotarget. 2016; 7: 68012-22.

83. Patel P, Tsiperson V, Gottesman SRS, Somma J, Blain SW. Dual Inhibition of CDK4 and CDK2 via Targeting p27 Tyrosine Phosphorylation Induces a Potent and Durable Response in Breast Cancer Cells. Molecular cancer research : MCR. 2018; 16: 361-77.

84. Patel P, Asbach B, Shteyn E, Gomez C, Coltoff A, Bhuyan S, et al. Brk/Protein tyrosine kinase 6 phosphorylates p27KIP1, regulating the activity of cyclin D-cyclin-dependent kinase 4. Molecular and cellular biology. 2015; 35: 1506-22.

85. Blain SW. Switching cyclin D-Cdk4 kinase activity on and off. Cell cycle (Georgetown, Tex). 2008; 7: 892-8.

86. Shee K, Jiang A, Varn FS, Liu S, Traphagen NA, Owens P, et al. Cytokine sensitivity screening highlights BMP4 pathway signaling as a therapeutic opportunity in ER(+) breast cancer. FASEB journal : official publication of the Federation of American Societies for Experimental Biology. 2019; 33: 1644-57.

87. Xing Z, Zhang Y, Zhang X, Yang Y, Ma Y, Pang D. Fangchinoline induces G1 arrest in breast cancer cells through cell-cycle regulation. Phytotherapy research : PTR. 2013; 27: 1790-4

88. Wang B, Xing Z, Wang F, Yuan X, Zhang Y. Fangchinoline inhibits migration and causes apoptosis of human breast cancer MDA-MB-231 cells. Oncology letters. 2017; 14: 5307-12

89. Lin HJ, Hsieh FC, Song H, Lin J. Elevated phosphorylation and activation of PDK-1/AKT pathway in human breast cancer. British journal of cancer. 2005; 93: 1372-81.

90. Jansen VM, Bhola NE, Bauer JA, Formisano L, Lee KM, Hutchinson KE, et al. Kinome-Wide RNA Interference Screen Reveals a Role for PDK1 in Acquired Resistance to CDK4/6 Inhibition in ER-Positive Breast Cancer. Cancer research. 2017; 77: 2488-99.

91. Liu P, Begley M, Michowski W, Inuzuka H, Ginzberg M, Gao D, et al. Cell-cycle-regulated activation of Akt kinase by phosphorylation at its carboxyl terminus. Nature. 2014; 508: 541-5.

92. Cretella D, Ravelli A, Fumarola C, La Monica S, Digiacomo G, Cavazzoni A, et al. The anti-tumor efficacy of CDK4/6 inhibition is enhanced by the combination with $\mathrm{PI} 3 \mathrm{~K} / \mathrm{AKT} / \mathrm{mTOR}$ inhibitors through impairment of glucose metabolism in TNBC cells. Journal of experimental \& clinical cancer research : CR. 2018; 37: 72.

93. Michaloglou C, Crafter C, Siersbaek R, Delpuech O, Curwen JO, Carnevalli LS, et al. Combined Inhibition of mTOR and CDK4/6 Is Required for Optimal Blockade of E2F Function and Long-term Growth Inhibition in Estrogen Receptor-positive Breast Cancer. Molecular cancer therapeutics. 2018; 17: 908-20.

94. Wee P, Wang Z. Epidermal Growth Factor Receptor Cell Proliferation Signaling Pathways. Cancers. 2017; 9.

95. De Luca A, Maiello MR, D'Alessio A, Pergameno M, Normanno N. The RAS/RAF/MEK/ERK and the PI3K/AKT signalling pathways: role in cancer pathogenesis and implications for therapeutic approaches. Expert opinion on therapeutic targets. 2012; 16 Suppl 2: S17-27.

96. Halilovic E, She QB, Ye Q, Pagliarini R, Sellers WR, Solit DB, et al. PIK3CA mutation uncouples tumor growth and cyclin D1 regulation from MEK/ERK and mutant KRAS signaling. Cancer research. 2010; 70: 6804-14.

97. Wang CZ, Yuan P, Li Y. MiR-126 regulated breast cancer cell invasion by targeting ADAM9. International journal of clinical and experimental pathology. 2015; 8: 6547-53.

98. Zhang J, Du YY, Lin YF, Chen YT, Yang L, Wang HJ, et al. The cell growth suppressor, mir-126, targets IRS-1. Biochemical and biophysical research communications. 2008; 377: 136-40.

99. Elumalai P, Arunkumar R, Benson CS, Sharmila G, Arunakaran J. Nimbolide inhibits IGF-I-mediated PI3K/Akt and MAPK signalling in human breast cancer cell lines (MCF-7 and MDA-MB-231). Cell biochemistry and function. 2014; 32: 476-84. 
100. Baldassari F, Zerbinati C, Galasso M, Corra F, Minotti L, Agnoletto C, et al. Screen for MicroRNA and Drug Interactions in Breast Cancer Cell Lines Points to miR-126 as a Modulator of CDK4/6 and PIK3CA Inhibitors. Frontiers in genetics. 2018; 9: 174 .

101. Yang C, Li Z, Bhatt T, Dickler M, Giri D, Scaltriti M, et al. Acquired CDK6 amplification promotes breast cancer resistance to CDK $4 / 6$ inhibitors and loss of ER signaling and dependence. Oncogene. 2017; 36: 2255-64.

102. Palmirotta R, Lovero D, Cafforio P, Felici C, Mannavola F, Pelle E, et al. Liquid biopsy of cancer: a multimodal diagnostic tool in clinical oncology. Therapeutic advances in medical oncology. 2018; 10: 1758835918794630.

103. Forshew T, Murtaza M, Parkinson C, Gale D, Tsui DW, Kaper F, et al. Noninvasive identification and monitoring of cancer mutations by targeted deep sequencing of plasma DNA. Science translational medicine. 2012; 4: 136 ra68.

104. Condorelli R, Spring L, O'Shaughnessy J, Lacroix L, Bailleux C, Scott V, et al. Polyclonal RB1 mutations and acquired resistance to CDK $4 / 6$ inhibitors in patients with metastatic breast cancer. Annals of oncology : official journal of the European Society for Medical Oncology. 2018; 29: 640-5.

105. Xu B, Krie A, De P, Williams C, Elsey R, Klein J, et al. Utilizing Tumor and Plasma Liquid Biopsy in Treatment Decision Making for an Estrogen Receptor-Positive Advanced Breast Cancer Patient. Cureus. 2017; 9: e1408.

106. Hu ZY, Xie N, Tian C, Yang X, Liu L, Li J, et al. Identifying Circulating Tumor DNA Mutation Profiles in Metastatic Breast Cancer Patients with Multiline Resistance. EBioMedicine. 2018; 32: 111-8.

107. Murtaza M, Dawson SJ, Tsui DW, Gale D, Forshew T, Piskorz AM, et al. Non-invasive analysis of acquired resistance to cancer therapy by sequencing of plasma DNA. Nature. 2013; 497: 108-12.

108. Page K, Guttery DS, Fernandez-Garcia D, Hills A, Hastings RK, Luo J, et al. Next Generation Sequencing of Circulating Cell-Free DNA for Evaluating Mutations and Gene Amplification in Metastatic Breast Cancer. Clinical chemistry. 2017; 63: 532-41.

109. de Melo Gagliato D, Jardim DL, Marchesi MS, Hortobagyi GN. Mechanisms of resistance and sensitivity to anti-HER2 therapies in HER2+ breast cancer. Oncotarget. 2016; 7: 64431-46.

110. Pernas S, Tolaney SM. HER2-positive breast cancer: new therapeutic frontiers and overcoming resistance. Therapeutic advances in medical oncology. 2019; 11: 1758835919833519.

111. Goel S, Wang Q, Watt AC, Tolaney SM, Dillon DA, Li W, et al. Overcoming Therapeutic Resistance in HER2-Positive Breast Cancers with CDK4/6 Inhibitors. Cancer cell. 2016; 29: 255-69.

112. Corona SP, Ravelli A, Cretella D, Cappelletti MR, Zanotti L, Dester M, et al. CDK4/6 inhibitors in HER2-positive breast cancer. Critical reviews in oncology/hematology. 2017; 112: 208-14.

113. Ponde N, Brandao M, El-Hachem G, Werbrouck E, Piccart M. Treatment of advanced HER2-positive breast cancer: 2018 and beyond. Cancer treatment reviews. 2018; 67: 10-20.

114. Brandao M, Ponde NF, Poggio F, Kotecki N, Salis M, Lambertini M, et al. Combination therapies for the treatment of HER2-positive breast cancer: current and future prospects. Expert review of anticancer therapy. 2018; 18: 629-49.

115. Goel S, DeCristo MJ, Watt AC, BrinJones H, Sceneay J, Li BB, et al. CDK4/6 inhibition triggers anti-tumour immunity. Nature. 2017; 548: 471-5.

116. Goel S, DeCristo MJ, McAllister SS, Zhao JJ. CDK4/6 Inhibition in Cancer: Beyond Cell Cycle Arrest. Trends in cell biology. 2018; 28: 911-25.

117. Schaer DA, Beckmann RP, Dempsey JA, Huber L, Forest A, Amaladas N, et al. The CDK4/6 Inhibitor Abemaciclib Induces a T Cell Inflamed Tumor Microenvironment and Enhances the Efficacy of PD-L1 Checkpoint Blockade. Cell reports. 2018; 22: 2978-94.

118. Chaikovsky AC, Sage J. Beyond the Cell Cycle: Enhancing the Immune Surveillance of Tumors Via CDK4/6 Inhibition. Molecular cancer research : MCR. 2018; 16: 1454-7.

119. Laphanuwat P, Jirawatnotai S. Immunomodulatory Roles of Cell Cycle Regulators. Frontiers in cell and developmental biology. 2019; 7: 23.

120. Zhang J, Bu X, Wang H, Zhu Y, Geng Y, Nihira NT, et al. Cyclin D-CDK4 kinase destabilizes PD-L1 via cullin 3-SPOP to control cancer immune surveillance. Nature. 2018; 553: 91-5. 